\title{
Géza Maráczi
}

\section{"A Peculiar Fusion of Soul"}

\section{Narration, Characterisation, and the Self in Sons and Lovers}

\begin{abstract}
In an attempt to integrate the study of characterisation with that of narration in D. H. Lawrence's Sons and Lovers, this paper traces the psychological themes whose realisation structures the narrative techniques of character presentation and the types of discourse applied for establishing and presenting the psychologies of characters. It examines the narrative techniques the novel employs for characterisation and describes, in terms of narrative situations, focalization and the technique of free indirect discourse, its methods for presenting the mental activities of the characters. It finds that by means of constant shifts of focalization within two specific types of discourse ("psycho-narration" and "narrated monologue"), the narrative accomplishes the linguistic representation of the psychological themes that can be defined as 'the dislocation of sensibility' and 'the loss of the self,' and explains them accordingly.
\end{abstract}

Following the dominant line in its criticism and reception, Sons and Lovers may be considered a variety of the autobiographical novel regarding its plot and characters as based on events and people in the life of the novelist. This aligns it with James Joyce's A Portrait of the Artist as a Young Man, with which it has been frequently compared, and raises a few considerations about the degree of fictionality involved in character presentation. I attribute only a limited validity to interpretational strategies influenced by the autobiographical element but assume that modes of narrating are not only the means of establishing characters' psychologies here, but the creation of a linguistic realisation for the author's psychology takes place, which is performed by way of transposing it into the consciousness of a third-person fictional character, as well as by the employment of narrative modes for presenting consciousness and narrative perspective ("focalization") - formal elements of narrative situation.

Therefore, further to discussing the narrative techniques the novel employs for characterisation, I will rely on concepts of the theories of narrative form - or, more precisely, the poetics of narrative fiction that have been developed by theorists fol- 
lowing the lead of Structuralist narratology - and concentrate on presenting how the novel's narrative, also by the employment of technical features of narration, constructs the representation of a particular psychological theme: the sense of a loss of the self in close emotional relationships.

\section{Characters in life vs. characters in fiction}

I assume that the creation of a novel basically involves giving linguistic expression to some psychological subject matter determined by a background of authorial concerns and intentions, a consciousness. Setting apart the issues of narrative situation for the moment, in the case of an autobiographical novel, or, specifically, a family 'saga,' it may often be prior among the novelist's motives and aims to gain an understanding of deeds, fates, emotions, relationships and inner selves of the characters one is writing about: characters who are for some measure derived from the actual characters of one's life. The technique here is the transferring of authorial concepts about the psychologies of those who served as models for the characters, into a fictional world, and embellishing them with qualities distinctive of the fictional from the actual or 'real.'

One may achieve suppressing one's knowledge of 'real-life' parallels of issues raised by their reading only with difficulty in the case of Sons and Lovers. Acquaintance with Lawrence studies ${ }^{1}$ undoubtedly shows that biographical literature on Lawrence and criticism of his work is more often than not overwhelmed by the interwoven nature of the principles of life and art. Indeed, when reading an account on the social and domestic background or the life story of the novelist, ${ }^{2}$ it is disturbing to become aware that one is reading at once about the setting, chief characters and central situations of this novel. One may have a sense that all the features and attributes of the work should not be so fully accounted for by, as it were, 'reality.'

The same may pertain to such complementary sources as extracts from letters by the author. In these Lawrence provides ready-made interpretations, startling explanations of his relationship with his mother and its effects on his emotional life, as well as complex expositions of his ideas on the plot and conflicts. He wrote to Edward Garnett, his editor: "I have written a great book. It's the tragedy of thousands of

1. Such as might be gained from the excellent up-to-date survey by Fiona Becket: The Complete Critical Guide to D. H. Lawrence (London and New York: Routledge, 2002).

2. Such as the one provided in: Allan Ingram, The Language of D. H. Lawrence (Basingstoke: Macmillan, 1990), pp. 19-44 and Becket, pp. 5-31. 
young men in England... Now tell me if I haven't worked out my theme, like life but always my theme."3

Giving shape by language, style, imagery, structure, rhythm and other features of form to material of personal experience is an undertaking that I consider a much more demanding one than the creation of an exclusively fictional narrative. Jessie Chambers in her memoirs remarked her admiration of the "spontaneous flow, the seemingly effortless translation of life" in the vivid rendering of family scenes, and noted what I regard as the most important observation: "It was his power to transmute the common experiences into significance that I always felt to be Lawrence's greatest gift."4

As Frieda Lawrence put it, writing about Lawrence's treatment of Miriam (modelled on Jessie Chambers): "In writing about her, he had to find out impersonally what was wrong in their relationship." 5 The point is that it is precisely this impersonal approach to his own life and the personalities known from it, through the dislocation of his consciousness along with the literary imaginative shaping process mentioned above, that yields such vividness and intimacy of character-presentation, and is so peculiar to Sons and Lovers. Then in the fictional world that has been provided with its own distinctive qualities, this is rendered highly personal, only, the personalities involved are those of the fictional characters, not those of the author's life any more. I have already alluded to the concept of autobiographically based novel-writing as a result of a quest for understanding one's life and self; in the case of Lawrence at least it does appear as a creative means of self-purification: "One sheds one's sicknesses in books - repeats and presents again one's emotions, to be master of them," 6 and helps others to achieve similar catharsis.

My approach to the novel is in accord with Gamini Salgado's opinion, who counsels that the "truth" of the novel "has to be judged in terms of the vividness, internal consistency and inclusiveness of its vision rather than by its accuracy as a chronicle." The answer to questions of the author's "fairness" to his characters "involves an account of them in their relation to each other and the fictional world they inhabit, and

3. "Extracts from Letters," in D. H. Lawrence: 'Sons and Lovers,' ed. Gamini Salgado (Basingstoke: Macmillan, 1969), 21-41, p. 25.

4. Cited in Ingram, p. 35.

5. Salgado, p. 29.

6. Salgado, p. 26. 
of the author's attitude to them as it appears in the details of the novel, not a measuring-off of the fictional characters against their real-life counterparts." 7

\section{Characterisation in a 'Naturalist Bildungsroman'}

In order to achieve such an account, having contemplated on how the fact that Lawrence used his own parents, siblings and female acquaintances as models for the characters in the novel influences the readers' and critics' approaches to the book; I may now examine its narrative features in the light of considering the novel a biography: that of Paul Morel. This may suggest a certain inclination towards the insights of criticism that relates Sons and Lovers to the Bildungsroman.

The central characteristic of its narrative structure is that it rests on the presentation of a sequence of relationships (or rather: on a sequential presentation of relationships), with only the necessary implications of chronology, rather than on narrating sequences of events. The presentation of the story does proceed in a straightforward manner, but it is realised by a constant shifting of the focus from one relationship to another, thus establishing a rhythm in its narration. A structuring principle of both story and narration ${ }^{8}$ is the similar shifting involvement of characters, which is responsible for the repetitions and occasional tenuousness in the presentation of characters by an omniscient narrator. 9

Frederick R. Karl and M. Magalaner reckon that Lawrence's efforts in "forcing an 'internal life' upon a recalcitrant character whose tendencies are almost entirely external" results in the lack of "differentiation and identifiable individuality" in his characters, "for all of them on occasion are Lawrence rather than themselves." 10 By contrast, it is precisely that effort and aim in which the narration of Sons and Lovers has accomplished the most. Applying the variation of an omniscient or external perspective with a plurality of internal perspectives, it reveals characters' internal lives by either indirectly describing their emotions or more directly reporting them (the focus of the second half of my paper). This is at the same time a technique of charac-

7. Gamini Salgado, "Introduction," in D. H. Lawrence: 'Sons and Lovers,' ed. Gamini Salgado (Basingstoke: Macmillan, 1969), 11-17, p. 13.

8. Both in the sense of narratological levels, put simply: story as what is narrated, narration is how it is narrated.

9. Later to be defined as "authorial narrative situation" and "narrator-focalizer."

10. Frederick R. Karl, M. Magalaner, A Reader's Guide to Great Twentieth Century English Novels (London: Thames and Hudson, 1961), 156-171, p. 156. 
terisation: implicating characters' emotions by showing and commenting on what may be perceived of them by other characters or the reader, whether this be the character's action, dialogue, tone or gesture. ${ }^{11}$ The point is that the vehicles of characterisation are action, interaction or even reaction. For indicating their reactions is also a means of revealing characters' inner lives, practised here by a narrator chiefly interested in the relationship between inner states of feeling and the outward expression of them.

This interest is in accord with the technique of emphasis "on cataloguing stimuli and responses" which is a demand of the Naturalist novel, according to Karl and Magalaner.12 The other would be "emphasis on cause and effect," which is in accord with the element of plot implied in the concept of Bildung, and as it is the case in Sons and Lovers: "plot may be downplayed in favour of the representation of a character's interiority ... but whenever events are presented in an order that implies relatedness, a minimal plot exists." 13

\section{The long exposition}

The comparatively simple theme of family tensions rooted in Mrs. Morel's disillusionment and lack of fulfilment in her socially and culturally unbalanced marriage is worked up into an extensive exposition in Part One; providing an exhaustive presentation of the marriage of Paul's parents, his childhood spent among his siblings, and his first experiences at work; with emphasis on the 'history' of Mrs. Morel's emotions for her husband and two of her four children, two of her three sons. At this stage, the Bildungsroman is rather a domestic novel, rather a case history of the mother of the hero than of himself, already including three relationships by shifting focus (Morel $\leftrightarrow$ Mrs. Morel, Mrs. Morel $\rightarrow$ William, Mrs. Morel $\rightarrow$ Paul, with the latter to be expanded to involve conflicts only in Part Two).

The pace of narration varies between panoramic, i.e., summarising, and scenical narration. Narratology regards these as tools for variation of distance between the

11. As well as by abounding in various descriptions, often to minute details mostly concerning appearances (items of clothing, objects in parlour, views of the country from window, doorway, entry, roadside, train, etc.) and financial issues (curiously all wages, prices and costs are recorded!) in a thorough fashion; but mainly exercising such a full power only when required to assert the symbolism of certain scenes.

12. Karl and Magalaner, p. 156.

13. Susan Keen, Narrative Form (Basingstoke: Macmillan, 2003), p. 75. 
narrated situations and events, and their narration; ${ }^{14}$ which is, along with perspective, one of two major factors that regulate narrative information. To clarify using Gérard Genette's terms: the technique of "acceleration" corresponds to summary pace, while "deceleration" to scene pace. ${ }^{15}$ In the presentation of relationships, the narration of scenes of characterising function and force is what dominates, which are scenes of no more than a few pages or even paragraphs of length and mostly without transition. Examples are Morel's cutting William's hair, Mrs. Morel's marketing, the parents' battles, William's visits home, Paul's destroying Annie's doll, Paul's collecting his father's wages, scenes of his life among the girls employed at the factory. Utterly similar to scenes and cuts in a film, each has some reference beyond themselves to psychological themes. Ranging beyond the narration of sequences of events drawn together by 'forces' of teleology or chronology, beyond common purposes of chronicling the life of the hero and his close associates, the emphasis seems to be on how they lived, not on what happened to them. This holds fairly true for the whole span of time narrated in the novel.

The impression is as if the narration's aim and objective were constantly being altered, as if to give the reader a broad vista, but this with the sense of prolonged occurrence in time or even floating in timelessness. The majority of narrating phrases that present or report actions or exchanges of conversation that are crucial in characterisation, is introduced by would; and the pace suddenly decelerates to that of the scenical mode, while the reader only gets a vague impression whether what is being presented is told in the singulative (it happened once and is told once) or in the iterative mode (it happened an indefinite number of time but is told only once - a common technique also in Lawrence's later prose). ${ }^{16}$ This technique, which corresponds to the regulation of narrative information as well as to narrative perspective, is a tool for creating an all-embracing atmosphere and for comprehensive presentation of how certain patterns are established that will define the characters' lives, in accord with the concept of Bildung. Besides it is also a tool for attaining the reader's sympathy for the characters.

Contents of the scenes: dialogue and comments on exchanges of it, descriptive and expository prose, imagery, are tools of a characterisation that always derives

14. Gerald Prince, A Dictionary of Narratology (Lincoln and London: University of Nebraska Press, 1987), p. 22.

15. Shlomith Rimmon-Kenan, Narrative Fiction: Contemporary Poetics (London and New York: Routledge, 2002), pp. 53-56.

16. Rimmon-Kenan, pp. 57-58. 
from factors external to the characters - e.g., situations, objects of environment, emotional reaction to sensual experience -, as well as from action.

The example of the parents may be taken. Walter Morel receives the least inner description and is disproportionately revealed mainly from his wife's point of view (varying her internal and the narrator's external perspectives), which is a sign of evident bias on the "implied author's" part (who may be held responsible for ideological and emotional stances within the external perspective). Yet he is also presented in action: we get vivid scenes of him making his breakfast preferring his clasp knife to a fork, preparing and setting off for the mine, full accounts of his habits, his satisfied absorption at work and, despite the alienation of his domain, the ability to relate to his children by his practical skills. (They enjoy singing with, and attending to, him when mending things or making fuses for the mine.) What is not represented but easily deduced from even the weak scene of Morel among his "butties" (fellow miners), is that "the working-class man may come like Morel to exert a despotic authority in the household partly to compensate for his lack of power at work," and the "oppressive toil of the mine is likely to make for ... outright violence at home."17

What is presented, as a result of the external perspective, is only what is perceived of Morel by the family and his wife (here his alienation and sensuous nature, with objects, movements, etc., always seeming to have special significance), yet there are shifts into an internal perspective: ${ }^{18}$

Morel made the meal alone, brutally. He ate and drank more noisily than he had need. No one spoke to him. The family life withdrew, shrank away, and became hushed as he entered. But he cared no longer about his alienation. Immediately he had finished tea he rose with alacrity to go out. It was this alacrity, this haste to be gone, which so sickened Mrs. Morel. [Internal p.:] As she heard him sousing heartily in cold water, heard the eager scratch of the steel comb on the side of the bowl, as he wetted his hair, she closed her eyes in disgust. As he bent over, lacing his boots, there was a certain vulgar gusto in his movement that divided him from the reserved, watchful rest of the family.

17. Terry Eagleton, The English Novel (Oxford: Blackwell, 2005), 256-281, p. 269.

18. This I will later discuss within the theoretical framework of "focalization."

19. All parenthesised references are to this edition: D. H. Lawrence, Sons and Lovers (Harmondsworth: Penguin, 1977). 
And, likewise, his own history is narrated only by commenting on his wife's attitudes to him and on the manifestations of them, with the occasional adoption of her internal perspective:

Mrs. Morel was more tolerant of him, and he, depending on her almost like a child, was rather happy. Neither knew that she was more tolerant because she loved him less. [Internal p.:] Up till this time, in spite of all, he had been her husband and her man. She had felt that, more or less, what he did to himself he did to her. Her living depended on him. [External p.:] There were many, many stages in the ebbing of her love for him, but it was always ebbing.

There are also many instances presenting Mrs. Morel in action. Such as when ironing: "Her movements were light and quick. It was always a pleasure to watch her. Nothing she ever did, no movement she ever made, could have been found fault with by her children. The room was warm and full of the scent of hot linen. Later on the clergyman came and talked softly with her" (86). As in this quotation, her characterisation is often merged with the presentation of Paul's impressions of, and emotions for, her, even if these seem improbable or too abstract: "When she was quiet, so, she looked brave and rich with life, but as if she had been done out of her rights. It hurt the boy keenly, this feeling about her that she had never had her life's fulfilment: and his own incapability to make up to her hurt him with a sense of impotence, yet made him patiently dogged inside. It was his childish aim" (85).

The result of the increasing concentration on the relationship between them is that Paul's characterisation, apart from slight physical description and scenes of him among playmates and workmates, partly anticipates the later focusing on his internal life, as in: "Then she pushed up her veil. Paul hated her for not being prouder with this common little man, and he loved her face clear of the veil," (p. 120) and many other comments inserted in dialogues. It is in there that depiction of how "the two shared lives," sensitivities and consciousnesses, is rooted, rather than in action. See for example their almost coquetting dialogue in the scene of their first journey to Willey Farm (pp. 152-155).20 These are all prefiguring how his emotional life would

20. Journeys are exclusively associated with the two of them: together to Nottingham for Paul's job-interview, to Willey Farm for the first time, than to Lincoln in Chapter IX, and Mrs. Morel's trip to London where William is dying, then her last one home from Sheffield to die in Chapter XIII. 
be dominated by his mother, which is illustrated by modes of presenting emotional life in Part Two.

Expressive functions and symbolic power of imagery are relevant as well. Lawrence "seems not to distinguish between the reality and the metaphor or symbol which makes it plain to us." ${ }^{21}$ But, as Dorothy Van Ghent says, "the most valid symbols are the most concrete realities," which is a feature of poetic language. All family scenes are perceivably suggestive of the core psychological themes, e.g., Mrs. Morel's hostility against her husband's means of wage-earning and social habits, emotional interdependence between mother and sons; or, later on, that Paul and his father have been marginalized and their emotional wholeness destroyed in more or less the same way by the domination of Mrs. Morel.

In Part Two, the comparatively longer and in every respect more verbose portion of the novel, the narration's concern is less with particularising the general, that is, establishing an overall atmosphere about the passage of time and characters' ways of life, constructed by illustrative individual scenes full of indications to be deciphered; but rather with generalising the particular, that is, constituting a parabolic case history out of underlying psychological themes: creating the impression that the individuals' actions and interactions which the narration represents, are manifestations of motives rooted in the general themes.

These themes may either be the impossibility of fulfilment in love when its physical and spiritual components are split apart (the relationship with Clara, but partly with Miriam as well) or the causes of this split in the possessive deviations of maternal and youthful love (relationships with Mrs. Morel and Miriam, their antagonism and parallelisms: both demanding Paul's full self in their loves for him). Paul's situation with respect to them would always appear as indicative of something generally human. Technically, this entails that what was implicit concerning the emotional setting of William's being torn apart between Miss Western and his mother, and his consequent death (in some respects a prefiguration of Paul's fate, yet there was no reporting of William's mental suffering); will become fully explicit in Paul's case history.

The technique of presentation is still rooted in the succession of scenes, yet by the turn of Part One and Two the focus is somewhat abruptly transferred from the documentation of the external to that of the internal. The former (life among the working class of the Midlands) will henceforward constitute only a symbolic back-

21. Fergusson, quoted in Dorothy Van Ghent, "On 'Sons and Lovers,'” in D. H. Lawrence: 'Sons and Lovers,' ed. Gamini Salgado (Basingstoke: Macmillan, 1969), 112-129, p. 115. 
ground to the latter, family scenes being incorporated in the context of Paul's intellectual, artistic development and emotional conflicts. While in Part One the chief concern was character presentation, here the reader may more easily witness narration's achievements in revealing characters' internal lives.

\section{Narrative situations and focalization}

The concept of characterisation has to be broadened at this point so as to include the techniques for presenting the psychologies of characters: the depiction of phases of emotional development and states of mind, the representation of emotions and consciousnesses. The second half of my paper will be concerned with these techniques in Sons and Lovers, and I take them to point further than those I have analysed in connection with characterisation, and to be operations that are performed not exclusively on the "text" level (which Genette labelled "narrative") but on that of "narration" (Genette's "narrating"), that of "the "how' of a narrative as opposed to its 'what,' the narrating as opposed to the narrated." 22

The fundamental distinction of narrative levels in narratology originates from Russian Formalism's distinction between fabula and sjuzet, further distinguished by Structuralists: Tzvetan Todorov's "story" vs. "discourse" and Genette's influential system of "story" (histoire in the French original), "narrative" (récit) and "narrating" (narration), ${ }^{23}$ that has been transposed into Poststructuralist narratology as levels labelled either as "fable," "story" and "narrative text" (in Mieke Bal's influential system), or simply as "story," "text" and "narration." Shlomith Rimmon-Kenan introduces them as follows:

'Story designates the narrated events, abstracted from their disposition in the 'text' and reconstructed in their chronological order, together with the participants in these events. ... 'Text' is a spoken or written discourse which undertakes their telling. ... In it, the events do not necessarily appear in chronological order, the characteristics of the participants are dispersed throughout, and all the items of the narrative content are filtered through some prism or perspective ('focalizer'). Since the text is a spoken or

\footnotetext{
22. Prince, p. 21.
}

23. Gérard Genette, Narrative Discourse. An Essay in Method, trans. Jane E. Lewin (Ithaca, New York: Cornell University Press, 1980), pp. 25-32. 
written discourse, it implies someone who speaks or writes it. The act or process of production is the third aspect - 'narration.'24

Conversely, in my view, it is the third category or level that accounts for the perspectives of narrative presentation, ${ }^{25}$ since they are determined by the narrative situation, which is created on this level. ${ }^{26}$ "In the empirical world, the author is the agent responsible for the production of the narrative and for its communication," ${ }^{27}$ while narrative situation is the communication situation in the fictional world. It is the framework in which the narrative performs its communication, effects or functions of which derive from all three levels just mentioned. Characterisation is such an effect, being the achievement of narrative techniques that are themselves determined by the narrative situation chosen. So are the modes for presenting characters' thoughts and emotions.

Franz K. Stanzel describes narrative situations considering narration as mediating activity according to three "axes," those of person, mode and perspective. The category of person refers to first-person narrative situation, where the level of existence of the narrator is identical with that of the characters. In "authorial" narrative situation, ${ }^{28}$ "the narrator's world exists on a different level of being from that of the characters. Here the process of transmission originates from an external perspective." 29 Whereas "figural" narrative situation is the mode when narration illusorily appears as non-mediated, "the narrative conveys the illusion of unmediated access to

\section{Rimmon-Kenan, p. 3.}

25. This is a controversial issue in post-Genettean theory, see for instance: Rimmon-Kenan, p. 86.

26. It is also this level that includes the "narrating instance" (by Bal, Prince and others), that has frequently been the subject of inquiries, because this is the level that hosts the "implied author" together with the roles of the reader, ranging from "narratee" to "implied reader."

27. Rimmon-Kenan, p. 4.

28. I consider this an unfortunate choice of terminology, for apart from implying the concept of authority in the mode of presentation, it may suggest reading strategies that involve relying to an overwhelming extent on information about the author's personality and on identifying impressions of it on the elements of the fictional world of the novel. This is of course a valid aspect, but its predominance should be avoided.

29. Franz K. Stanzel, A Theory of Narrative (Cambridge: Cambridge University Press, 1984), p. 5 . 
the main protagonist's mind and there is no foregrounded narrator persona,"30 but a character in the novel "who thinks, feels and perceives, but does not speak to the reader like a narrator." 31 The most important is that "the reader looks at the other characters of the narrative through the eyes of this reflector-character" 32 - this is the character, or rather an agent of narrative just like the narrator itself, that Genette defined (see Rimmon-Kenan above), and I will refer to, as "focalizer."

The nature of interrelationship in a particular text between the dominance or predominance of the narratorial ("authorial") or figural perspectives is what determines the nature of the narrative situation, and it is in this sense (also with a view on offering a useful synthesis of theoretical approaches) that I apply the concept of "focalization": 33 "the perspective in terms of which the narrated situations and events are presented; the perceptual or conceptual position in terms of which they are rendered." 34 It has been devised in narratology by Genette in order to enable discussion to distinguish between the two related but different questions of 'who speaks' and 'who sees' what is told. "Speaking and seeing, narration and focalization, may, but need not, be attributed to the same agent. The distinction between the two activities is a theoretical necessity, and only on its basis can the interrelations between them be studied with precision." 35

As regards its position relative to the level of the story, "focalization can be either external or internal to the story. External focalization is felt to be close to the narrating agent, and its vehicle is therefore called 'narrator-focalizer.' " ${ }_{6}^{6}$ Conversely, "the locus of internal focalization is inside the represented events. This type generally takes the form of a character-focalizer" (but this is not the case as a rule, so I will designate it in my examples as IF).

30. Monika Fludernik, "Histories of Narrative Theory (II): From Structuralism to the Present," in A Companion to Narrative Theory, ed. James Phelan, Peter J. Rabinowitz (Oxford: Blackwell, 2005), 36-59, p. 40.

31. Stanzel, p. 5 .

32. Stanzel, p. 5 .

33. It has emerged in narratology from the concept of point of view, established by earlier theoretical discussion but recently re-examined by text linguistics and critical linguistics in various contexts (e.g., those of ideology and speech act theory).

34. Prince, pp. 31-32.

35. Rimmon-Kenan, p. 73.

36. Rimmon-Kenan, p. 75. In Genette's original system, the term for this was "zerofocalization" ("external focalization" is confusingly used in a different sense); I refer to it as external or narratorial focalization and designate it in my examples as NF. 
Focalization has an object as well, what the narrative is focalized on, in terms of Mieke Bal's system: the focalizer "is the agent whose perception orients the presentation, whereas the object (the 'focalized') is what the focalizer perceives." 37

Then the last one of the important theoretical issues is that "the focalized can be perceived either from without or from within." The first type does not, while "the second type reveals the 'inner life' of the focalized, ${ }^{8}$ either by making him his own focalizer (interior monologues are the best example) or by granting an external focalizer (a narrator-focalizer) the privilege of penetrating the consciousness of the focalized." 39 The concern of the next section of my paper is the varieties of this in Sons and Lovers.

It is not to be forgotten that the narrative situations that I described are prototypes, or better, extremities on the mentioned "axes" of possibilities that Stanzel introduces by indicating continuity on a "typological circle," and texts combine characteristics of these narrative situations. Stanzel labels as "authorial-figural continuum" the "frequent move of the narrative between external and internal perspectives in a given section of the narrative."40 Narration in Sons and Lovers does this, by occasionally almost paragraph-by-paragraph shifts between the two third-person narrative situations, further varied by almost sentence-by-sentence shifts in focalization.

Generally speaking, the figural mode is dominant in the scenically oriented presentation of the emotional relationships in which Paul is involved, and basically in Part II; with mostly him, Miriam and, less frequently than in Part I, Mrs. Morel as focalizers (while Clara is often felt to be 'left behind'), yet the balance between internal and narratorial focalization is fairly maintained. The relevant qualities are the constant shifting in the focalizer-focalized relation and the narrative situation, as well as the effects of these that I will describe below. This novel would not be termed by narratologists to be primarily figural, since the 'authorial' narrative situation is

37. Rimmon-Kenan, p. 75. Genette's and Bal's models of focalization gave rise to extensive theoretical disputes, a full grasp of which could by no means inform my present discussion, but the formulations that orient it, are: W. Bronzwaer, "Mieke Bal's Concept of Focalization: A Critical Note," Poetics Today 2 (1981) 193-201. Monika Fludernik, "New Wine in Old Bottles? Voice, Focalization, and New Writing," New Literary History 32 (2001) 619-638. Göran Nieragden, "Focalization and Narration: Theoretical and Terminological Refinements," Poetics Today 23 (2002) 685-697.

38 . In my view, in such cases a character is only the source of what is focalized.

39. Rimmon-Kenan, p. 82.

40. Fludernik, A Companion to Narrative Theory, p. 41. 
still favoured in the frequent summaries of development in Paul's mental life and the previously discussed panoramic presentations of all sorts of events and background details, together with the narrative techniques of characterisation. The novel abounds in narratorial summaries more than it is customary with Modernist texts.

\section{Focalization and modes of presenting consciousness}

In identifying the techniques of presenting characters' thoughts and emotions in the novel, ${ }^{41}$ I rely on Dorrit Cohn's description of three basic categories for third-person narration: "psycho-narration," "quoted interior monologue" and "narrated monologue." Her system is the result of an efficient synthesis of earlier typological approaches to modes of representing speech and thought.

The most indirect type of discourse is psycho-narration (PN in examples): "the narrator's discourse about a character's consciousness." 42 It is associated with the authorial narrative situation, that "combines an omni-communicative narratorial presence up and above the world of fiction ... with a panoramic view of the fictional world and easy access to characters' thoughts and emotions":43

[NF:] She saw the dark yews and the golden crocuses, then she looked gratefully. [IF, $P N$ :] He had not seemed to belong to her among all these others; he was different then - not her Paul, who understood the slightest quiver of her innermost soul, but something else, speaking another language than hers. How it hurt her, and deadened her very perceptions. Only when he came right back to her, leaving his other, his lesser self, as she thought, would she feel alive again. And now he asked her to look at this garden, wanting the contact with her again. [NF, $P N$ :] Impatient of the set in the field, she turned to the quiet lawn, surrounded by sheaves of shut-up crocuses. A feeling of stillness, almost of ecstasy, came over her. It felt almost as if she were alone with him in this garden.

(204-205)

41. I am aware that the following part would ideally need much more textual illustration than what could be provided here.

42. Dorrit Cohn, Transparent Minds: Narrative Modes for Presenting Consciousness in Fiction (Princeton: Princeton University Press, 1978), p. 14.

43. Fludernik, A Companion to Narrative Theory, p. 40. 
Scenical presentation seems to alternate with summarising psycho-narration: "mental descriptions in a large time frame ... surveys of a temporal span," 44 presented in the form of omniscient short accounts (as it were, occasionally inserted pieces of information) of inner states and processes of feelings and attitudes, both drawn as results of represented interactions - with constant particular care driven to account for the emotional origins and many other reasons of them. As the narration proceeds, one may notice in these accounts a tendency of becoming increasingly abstract (e.g., working with concepts rather than providing the expressive imagery as well), and this later on would occasionally shake their impression of unquestionable acceptability, pointing to their lack of self-evidence as 'natural' insights.

Such obsessivity of indirect thought-presentation, as Allan Ingram suggests, draws attention to a self-conscious presence distancing and reducing the tension created through awakening sympathy for the characters. 45 Yet the dominance is of occasions when psycho-narration is combined with the more direct technique of the narrated monologue (NM in examples), which is basically a discourse constituted by the reporting of thoughts and other inner processes: "rendering a character's thought in his own idiom while maintaining the third-person reference and the basic tense of narration." 46

[NF, PN:] So to Miriam, Christ and God made one great figure, which she loved tremblingly and passionately when a tremendous sunset burned out the western sky, and Ediths, and Lucys, and Rowenas, Brian de Bois Guilberts, Rob Roys, and Guy Mannerings, rustled the sunny leaves in the morning, or sat in her bedroom aloft, alone, when it snowed. That was life to her. . . . On the whole, she scorned the male sex. [IF, PN:] But here was a new specimen, quick, light, graceful, who could be gentle and who could be sad, and who was clever, and who knew a lot, and who had a death in the family. ... Then he was so ill, and she felt he would be weak. [IF, NM:] Then she would be stronger than he. Then she could love him. If she could be mistress of him in his weakness, take care of him, if he could depend on her, if she could, as it were, have him in her arms, how she would love him!

(177-178)

"Narrated monologue" is Cohn's term for a technique of representing speech and thought, which is also customarily called "free indirect discourse" (so I will have

44. Cohn, p. 37.

45. Ingram, p. 40.

46. Cohn, p. 100. 
to refer to it by both terms); yet the distinction that has to be made, whether speech or thought is reported, is not obvious enough. She defines it as "a character's mental discourse in the guise of the narrator's discourse." 47 Yet, when it comes to analysing types of discourse applied for reporting the mental activities of characters, it cannot be disputed, that - in third-person narration - in the case of these two of the three major techniques, the source of discourse is still the narrator, ${ }^{48}$ who "continues to narrate, becoming the neutral but indispensable accessory to figure-oriented narration"; 49 even if the source of perception is transferred into a character (internal focalizer). The narrative of Sons and Lovers most frequently inserts passages of narrated monologue between turns of dialogues, creating the impression of representing 'live' process of mental activity:

[IF, PN:] Miriam pondered this. She saw what he was seeking - a sort of baptism of fire in passion, it seemed to her. She realised that he would never be satisfied till he had it. [IF, NM:] Perhaps it was essential to him, as to some men, to sow wild oats; and afterwards, when he was satisfied, he would not rage with restlessness any more, but could settle down and give her his life into her hands. Well, then, if he must go, let him go and have his fill - something big and intense, he called it. At any rate, when he had got it, he would not want it - that he said himself; he would want the other thing that she could give him. He would want to be owned, so that he could work. [IF, PN:] It seemed to her a bitter thing that he must go, but she could let him go into an inn for a glass of whisky, so she could let him go to Clara, so long as it was something that would satisfy a need in him, and leave him free for herself to possess.

Allan Ingram and Randall Stevenson identify what I regard as the most important aspects of the function of narrated monologue or free indirect discourse in Lawrence's novels, when they observe the narrator's tendency to "take for himself the freedom to shift between authorial assertion and thoughts that are unquestionably the character's own, or even the thoughts of more than one character";50 and that "Lawrence's writing destabilises the ego, dissolving any easy, secure sense of identity

47. Cohn, p. 14 .

48. While in the case of the third type, the quoted interior monologue, the character may be considered to be the source of discourse, it is "the character's mental discourse," (Cohn, p. 14) and there may or may not be a narrator who quotes it.

49. Cohn, p. 26.

50. Ingram, p. 101. 
in the voice of author or character, increasingly fused together in various shades and tones of intermingling." ${ }^{1}$

Let me only take as examples two different passages that employ free indirect discourse (customarily referred to as FID) to illustrate emotions of (either) Miriam and (or) Paul, where the prominence and significant deictic roles of personal and possessive pronouns, which is characteristic of free indirect discourse (and has been extensively studied in connection with it), may also be witnessed:

[NF:] "But what has happened?" she said.

"Nothing - it's all in myself - it only comes out just now. We're always like this towards Easter-time."

[IF, Miriam focalizer, Paul focalized, PN:] He grovelled so helplessly, she pitied him. [NM:] At least she never floundered in such a pitiable way. After all, it was he who was chiefly humiliated.

[NF:] "What do you want?" she asked him.

"Why - I mustn't come often - that's all. Why should I monopolise you when I'm not - You see, I'm deficient in something with regard to you - “

[IF, Miriam focalizer, NM:] He was telling her he did not love her, and so ought to leave her a chance with another man. How foolish and blind and shamefully clumsy he was! What were other men to her! What were men to her at all! But he, ah! she loved his soul. Was he deficient in something? Perhaps he was.

[NF:] "But I don't understand," she said huskily. "Yesterday -“

[IF, Paul focalizer, $P N$ :] The night was turning jangled and hateful to him as the twilight faded. [IF, Paul focalizer or NF, Miriam focalized, PN:] And she bowed under her suffering.

[NF:] "I know," he cried, "you never will! You'll never believe that I can't - can't physically, any more than I can fly up like a skylark -“

"What?" she murmured. [PN:] Now she dreaded.

"Love you."

[NF, Paul focalized, PN:] He hated her bitterly at that moment because he made her suffer. [IF, Miriam focalizer, Paul focalized (but the transition is uncertain, almost imperceptible even in deictics), NM:] Love her! She knew he loved her. He really belonged to her. This about not loving her, physically, bodily, was a mere perversity on his part, because he knew she loved him. He was stupid like a child. He belonged to her. His soul wanted

51. Randall Stevenson, Modernist Fiction: an Introduction (New York, 1992), p. 33. 
her. She guessed somebody had been influencing him. She felt upon him the hardness, the foreignness of another influence.

[NF:] "What have they been saying at home?" she asked.

"It's not that," he answered.

$[I F, P N:]$ And then she knew it was. She despised them for their commonness, his people. [NM:] They did not know what things were really worth.

[NF:] He and she talked very little more that night. After all he left her to cycle with Edgar.

(271-272)

They parted. [NF, Paul focalized, $P N$ :] He felt guilty towards her. [NF, Miriam focalized, PN; or IF: Paul focalizer, Miriam focalized, NM:] She was bitter, and she scorned him. He still belonged to herself, she believed; [IF, Miriam focalizer, Paul focalized, NM:] yet he could have Clara, take her home, sit with her next his mother in chapel, give her [all 3 for Clara] the same hymn-book he had given herself [Miriam] years before. [NF or IF, Miriam focalizer:] She heard him running quickly indoors....

$[N F, P N:]$ His heart went hot, and he was angry with them [Mrs. Morel \& Clara] for talking about the girl [Miriam]. [NM:] What right had they to say that? [PN:] Something in the speech itself stung him into a flame of hate against Miriam. Then his own heart rebelled furiously at Clara's taking the liberty of speaking so about Miriam. [NM:] After all, the girl was the better woman of the two, he thought, if it came to goodness....

[NF, Miriam focalized; or IF, Miriam focalizer, Paul focalized:] In chapel Miriam saw him find the place in the hymn-book for Clara, in exactly the same way as he used for herself. [Repetition of pattern] [IF, Paul focalizer, Miriam focalized:] And during the sermon he could see the girl across the chapel, her hat throwing a dark shadow over her face. [NM:] What did she think, seeing Clara with him? [NF, Paul focalized, $P N$ :] He did not stop to consider. He felt himself cruel towards Miriam [final recursion of pattern].

(396-397)

As reading proceeds through a host of scenes narrated like these, one will ultimately be unavoidably concerned with questions such as: While the narrator is telling, who is perceiving a character's feelings, the narrator or the character? If the latter, which one, at a particular point? For it is the accumulated impression that counts, with effects like this; and they recurrently occur whenever a scene is pre- 
sented that involves Miriam, Mrs. Morel or Clara (in the latter's case, it is less emphatic) together with Paul.

The instability and indefiniteness of the source of perception (focalizer) triggers the indefiniteness of the source of the focalized: the thoughts and emotions that are perceived by the focalizer and reported by the narrator. (This, the character who is the source of what is focalized, I designate in my examples simply as focalized, for brevity's sake.) On the one hand, the intriguing point is that not only the focalizer, but along with it the focalized is involved as well in constant temporary shifting: that of the source of perception from one focalizer character into the other; so the thoughts and emotions of the first character becomes focalized, and the other, who is the source of what was previously focalized, becomes focalizer - and this happens reciprocally and repeatedly, woven into strongly inter-related and coherent sentences. The effect is that the characters are presented as perceiving each other's thoughts and emotions, occasionally even on the cost of risking the apparent impossibility of this. But the situation is saved by the fact that while a character's position of perception is adopted (hence the apparent directness of presentation: free indirect discourse), the immediate source of the reporting discourse is the narrator (it is free indirect discourse).

On the other hand, the effect that the source of perception not only alternates between lying in the narrator and in a character (NF vs. IF), but also between lying in one character and the other, causes that discerning the locations of the two at a particular point requires additional effort on the part of the reader, which is a recurrent difficulty in a considerable number of passages. The indefiniteness of the focalizer and that of the source of what is focalized both have a puzzling effect, in repeatedly frustrating the inferences and attributions that are created as reading proceeds.

The basic approaches in research of FID assume that its intrinsic characteristics of uncertainty and indefiniteness should more be considered results of intermingling (I will mention the theory of a "dual perspective" later), rather than of alternation of "voices" or perspectives (in my approach, focalizations). Besides, intermingling or alternation of several possible internal focalizations (i.e., of different characterfocalizers with shifts in the focalized as well, respectively, as in Virginia Woolf's or Lawrence's later novels as well) is also much less taken into account, than mingling and alternation of narratorial and internal focalizations. My opinion is that all these aspects of this type of discourse equally contribute to its effects. 


\section{A background to the technique}

Free indirect discourse has long been the subject of excessive research in stylistics ever since the end of the 19th century. It was initiated by German and French linguists and this had inspired issues in the work of Franz K. Stanzel from the 1950s on, itself an inclusive embodiment of German narrative theory, but it was only by the 1970 s that a comprehensive linguistic theory of it has been constructed (Banfield, McHale) and related to mietic (Ron, Hernadi) and speech act theory (Lanser), and beyond, to concerns of narratology, primarily to the concept of focalization (Bal, Fludernik). Awareness of the background is here necessary only in order to give orientation to my discussion, so I limit it to an indication of the typological and theoretical formulations that have inspired my understanding of the phenomena and prompt to further studies. $5^{2}$

The question with which research on free indirect discourse (FID) has been chiefly concerned is that of the number, and sources, of 'voices' that can be 'heard' simultaneously in speech and thought representation. One of the assumptions is that it is a discourse "in which the narrator says in propria persona what one of the characters means. In such discourse, the authorial and the figural perspective need not alternate; rather, their simultaneous presence results in a new, dual mode of vision." 53 As research has showed, this is characteristic of the narrator's discourse already in several 19th-century novels as well as in earlier ones. ${ }^{54}$ Yet in the narration of Lawrence's work, as I attempted to demonstrate, the two perspectives may be perceived as alternating, rather than creating this dual mode, which would mean that the verbal and mental discourse of the character (this discourse itself as a fictional

52. Mike Bal, "Notes on Narrative Embedding," Poetics Today 2 (1981) 41-59. Ann Banfield, Unspeakable Sentences: Narration and Representation in the Language of Fiction (Boston: Routledge and Kegan Paul, 1982). Monika Fludernik, The Fictions of Language and the Languages of Fiction: The Linguistic Representation of Speech and Consciousness (London and New York: Routledge, 1993). Susan S. Lanser, The Narrative Act: Point of View in Fiction (Princeton: Princeton University Press, 1981). Brian McHale, "Free Indirect Discourse: A Survey of Recent Accounts," PTL 3 (1978) 249-288. Stanzel cited, for Hernadi and Ron, see below.

53. Paul Hernadi, "Dual Perspective: Free Indirect Discourse and Related Techniques," Comparative Literature 24 (1972) 32-43, p. 36.

54. For detailed discussion in this vein of examples from Flaubert's, Dostoevsky's and, most characteristically, Jane Austen's works, see: Roy Pascal, The Dual Voice: Free Indirect Speech and its Functioning in the Nineteenth-century European Novel (Manchester: Manchester University Press, 1977). 
construct) stylistically influenced, "coloured" the discourse of the narrator, so one felt to read both at the same time. In cases of inner presentation of characters in Sons and Lovers, the alternation that is produced by the employment of FID, is perceptible incessantly within certain distinct passages, on the level of the perspectives of the characters.

Stanzel treats FID as an aspect of the narrative situation and, with a historical perspective in his analyses, considers it a tool for transition from authorial to figural narrative situation. He acknowledges the assumption of a dual perspective as "a special form of expression of the mediacy of narration," 55 but regards the uncertainty created by FID about the sources of linguistic utterances and thoughts narrated, basically as a technique in establishing the "authorial-figural continuum." He does not take into consideration enough the possibilities for intermingling of not only the narrator's language and the characters' verbal and sub-verbal utterances, but also of those of the characters. ${ }^{6}$

The point of constructing a hypothesis of FID, undertaken by theorists indicated below, in the second half of the 2oth century, was to "arrive at an ... at best partial recuperation of the origin of utterances," 57 which are to be taken as comprising of reports on non-verbalised psychological content as well. It is also relevant, as it has been argued, that this effort is fruitful and indeed necessary "when the text is grasped as in some sense analogous to (mimetic of) reality," 58 in a mimetic concept, classifying representations of figural utterances in a framework derived from the classic dichotomy between mimesis and diegesis:

The concept of FID "can be meaningful only within literary mimesis, and its limits may be taken to mark some of the limits of the mimetic powers of language. ... The use of FID [hypothesis] is to seek to provide answers for questions concerning specific utterances in the mimetic text, such as: Whose words? Whose thoughts? Whose perceptions are these? Such answers are necessary in order to determine what is supposed to be happening in the story. Of course, they would not arise in the first place unless the

55. Stanzel, p. 191.

56. Stanzel, pp. 186-20o.

57. Rimmon-Kenan, p. 116.

58. Rimmon-Kenan, p. 116. 
utterances in question had been felt to be moot in respect of their attribution to a particular fictional subject. 59

My reading of Sons and Lovers is also attempting to attribute textual segments to factors that some FID-theorists call "speakers," but between which I differentiate as sources of perception and source of discourse (in the case of this novel, the latter invariably lies in the narrator). It probably only succeeds in emphasising the need to try this, nevertheless it owes the awareness of its theoretical background to articles by Moshe Ron and Paul Hernadi, though has to be limited here to a brief indication of this.

To gain fuller understanding, researchers compare FID, conceived of as modes of interrelation and alternation between perspectives or itself a dual perspective, a dual mode of signification, "to the function of verbal signs in exclusively authorial and exclusively figural discourse."6o My attempt only aimed at showing how alternations between these two types of discourses and perspectives, and more importantly between two figural perspectives (which I considered as sources of perception or focalizers and did not confuse with the source of discourse), occur and function in Sons and Lovers.

\section{'Psycho-narrative-analysis'}

On the basis of the foregoing description of narrative strategies and discussion of theoretical background, I find that the frequently perceptible uncertainty and indefiniteness of the source of perception (i.e., of the position of the focalizer) is the linguistic realisation of the psychological theme I identify as the 'dislocation of sensibility;' and the resulting indefiniteness of the source of the thoughts and emotions that are focalized, is the realisation of theme I consider the most important and conspicuous: the 'loss of the self' in relationships.

In the previous examples the obscurities that I have described arise from the strength of the represented emotional tie between Paul and Miriam, and present the phase of a relationship when feelings seem to merge, and (re-)cognition of them as well. Besides, it is precisely the loss of self the novel is to some extent about. It is what the social and cultural domination of Mrs. Morel causes in her husband; and,

59. Moshe Ron, "Free Indirect Discourse, Mimetic Language Games and the Subject of Fiction," Poetics Today 2 (1981), 17-39, pp. 17-18.

6o. Hernadi, p. 39. 
principally, the loss of Paul's self as a result of his emotional absorption in his mother's and Miriam's possessive loves for him; and it is also what the relationship with Clara proves to be an inefficient outlet for.

As Fiona Becket points out, "a growing preoccupation with self-consciousness can also be seen as a tendency in this novel. Paul Morel strives for self-definition first as an artist, than as a man. In the closing lines of the book, he achieves a sense of individual self-hood, free at last from the women in his life who have, up to that point, defined him." ${ }^{61}$ A Bildungsroman, then, will prove in a sense to be a venue where a healing of the loss of self is possible, by virtue of presenting selfexaminations of the hero, concentrating on his diverse relationships through scenical presentation of a series of encounters.

I regard these psychological themes as concepts constructed by a reader in order to facilitate a full understanding of the whole of information that the narrative presents about the inner lives of its characters. The like concepts are shaped, suggested by the types of discourse that is employed in presentation. With the foregoing explanation and demonstration (though the former tended to dominate due to spatial confinement), my aim was to convey how my concepts of this kind have been built up by the narrative. It is evident enough that the discourse about a character's inner life structures the patterns the reader will attribute to the psychology of the character, but this is part of a recursive process: the reader's conceptualisation of such themes is at best an unavoidably imperfect reconstruction of the themes that have originally structured the discourse, the themes to which the "implied author" 62 wants to give linguistic realisation. These in turn may eventually more or less correspond to the psychological concepts of the author himself, to his "sicknesses" he wanted to "shed" in the book, the emotions he wanted to "repeat and present again, to be master of them." 63

By my concept 'the loss of the self' I mean losing sense of, and ability to trace back, the origins of the states of feelings and emotions that one becomes conscious of in, and by, being involved in emotional intercourse with the other. As the case is here, this may be represented as a mutual exchange of a vision of each other's emotions between two characters; by expressing not only their emotions but their visions

61. Becket, p. 44.

62. A theoretical concept proposed by Wayne C. Booth, to be distinguished from the "flesh and blood person" and the narrator; together with the latter it is a fictional construct, "the implicit image of an author in the text, taken to be ... responsible for its design and for the values and cultural norms it adheres to" (Prince, p. 42).

63. See above, fn. 6. 
of the other's emotions, and not exclusively in moments that are given special significance. This is the 'dislocation of sensibility': becoming sensible of one's own emotions through, by means of, becoming sensible of those of the other. Being unconsciously brought to realise what the other feels, as temporarily indistinguishable for consciousness from one's own emotions, and alternating between the sense of the otherness of a particular feeling and the near conviction that the two persons really feel the same, or at least the conviction of precisely knowing what the other feels.

Representing this dislocation results in the realisation of the theme of 'the loss of the self: the obscurity and near impossibility of identifying which character is the one that feels an emotion that is represented or reported, which is produced by rapid shifts' obscuring which of them is the focalizer and which is the source of the thoughts and emotions that are focalized at a given point. As Ingram has perhaps more comprehensibly pointed out, this creates the impression of representing feelings that "do not necessarily belong to either one of two people, but rather exist between, are in the process of being played out between, both of them." 64

I think that, in a more abstract sense, the working of the themes that produced the 'textual phenomena' that I indicated, is also analogous with the process of identifications explained by the psychoanalyst and thinker Jacques Lacan's concepts of the "mirror stage" 65 and "imaginary phase" in the child's construction of a centre of self:

We arrive at a sense of an 'I' by finding that 'I' reflected back to ourselves by some object or person in the world. ... This object is at once somehow part of ourselves - we identify with it - and yet not ourselves, something alien. ... The imaginary for Lacan is precisely this realm of images in which we make identifications, but in the very act of doing so are led to misperceive and misrecognize ourselves. ${ }^{66}$

The ego is built up through making such imaginary identifications with objects as children will learn to perceive that "their identities as subjects are constituted by their relations of difference and similarity to the other subjects around them." 67

64. Ingram, p. 102.

65. Jacques Lacan, "The Mirror Stage as Formative of the Function of the I as Revealed in Psychoanalytic Experience," in Écrits: A Selection (London: Routledge, 1977), 1-7.

66. Terry Eagleton, Literary Theory: An Introduction (Oxford: Basil Blackwell, 1983), pp. 164-165.

67. Eagleton, Literary Theory, p. 167. 
The workings of similar processes in the characters' consciousnesses are also expressed by the narrative strategies that I have described. The identifications are made between the characters whose personalities and senses of their own selves are undergoing development and formation. More precisely, it is their emotions that are entering into such connection and through these their whole personalities as well. So their sense of identification with each other's emotions, which in reality is also misrecognition, a mistaking of their own emotions for those of the other and vice versa, entails the sense of identification between their personalities and selves, as this usually happens in a love relationship in life. This is the condition that proves suffocating for Paul Morel's sense of selfhood in all the three of his relationships that are presented: with his mother, with Miriam and with Clara.

Nonetheless, the sense of fulfilment of the self may also, and probably only, be achieved through experiencing this sense of losing it in a well-balanced relationship, as this is realised as well for brief periods of narrated time in some scenes that present phases of Paul's relationships with Mrs. Morel and Miriam. The kinds of identification processes characteristic of love relationships (and, in my view, of these only, among many possible forms of human contact), are also able to provide a real understanding of one's own emotions, which will entail the same with respect to those of the other, in a well-balanced relationship; and to bring about self-recognition and a sense of self-realisation.

This is the result of precisely what Lawrence described in a letter as "a peculiar fusion of soul," that characterised his relationship with his mother: "When it comes it seems to distribute one's consciousness far abroad from oneself, and one understands! I think no one has got 'Understanding' except through love."68

68. Salgado, p. 22. 